\title{
Perancangan Video Animasi Edukasi Penerapan Protokol Kesehatan Pencegahan COVID-19 Berbasis Motion Graphic
}

\author{
Anggi Elanda ${ }^{1}$, Darmansyah $^{2}$, Ahmad Fauzi $^{3}$ \\ ${ }^{1,2,3}$ Teknik Informatika, STMIK Rosma, Karawang \\ E-mail: anggi@rosma.ac.id
}

\begin{abstract}
In March 2020, the Indonesian Government officially announced that the Corona Virus disease had entered and began to spread in Indonesia. Corona virus or severe acute respiratory syndrome coronavirus 2 (SARS-Cov-2) is a virus that attacks the respiratory system. This disease due to viral infection is called COVID-19. The Corona virus can cause minor disturbances to the respiratory system, severe lung infections and can cause death. Corona virus is a type of disease that can be transmitted to humans. This virus can attack anyone, such as the elderly (elderly), adults, children and babies, including pregnant women and nursing mothers. With this news, the Government also reported that every Indonesian citizen is required to carry out social distancing, physical distancing, and lockdown to stop the spread of the covid-19 virus. Indonesian people are prohibited from gathering, carrying out events or activities that invite large numbers of people, and leaving activities that can be stopped, such as schools, campuses, and other places where it is possible to stop activities indefinitely. Therefore this study aims to educate and remind public awareness within the city of Karawang to continue implementing health protocols to break the chain of transmission of the Covid-19 disease.
\end{abstract}

Keywords: Covid-19, Information Media, Motion Graphic

\begin{abstract}
Abstrak
Pada bulan Maret 2020, Pemerintah Indonesia resmi memberitakan bahwa penyakit Virus Corona telah masuk dan mulai menyebar di Indonesia. Virus Corona atau severe acute respiratory syndrome coronavirus 2 (SARS-Cov-2) adalah virus yang menyerang sistem pernapasan. Penyakit karena infeksi virus ini disebut COVID-19. Virus Corona bisa menyebabkan gangguan ringan pada sistem pernapasan, infeksi paru-paru yang berat dan hingga dapat menyebabkan kematian. Virus Corona adalah jenis penyakit yang dapat menular pada manusia. Virus ini bisa menyerang siapa saja, seperti lansia (golongan usia lanjut), orang dewasa, anak-anak, dan bayi, termasuk ibu hamil dan ibu menyusui. Dengan adanya berita tersebut, Pemerintah juga memberitakan bahwa setiap warga Indonesia diharuskan untuk melakukan social distancing, physical distancing, dan lockdown guna menghentikan terjadinya penebaran virus covid-19 tersebut. Masyarakat Indonesia dilarang untuk berkumpul, melakukan acara atau berkegiatan yang mengundang banyak orang, dan meliburkan kegiatan yang bisa dihentikan seperti sekolah, kampus, serta tempat-tempat yang memungkinkan untuk menghentikan kegiatan sampai waktu yang tidak dapat ditentukan. Oleh karena itu penelitian ini bertujuan untuk mengedukasi serta mengingatkan kesadaran masyarakat dalam lingkup kota karawang untuk tetap menerapkan protokol kesehatan guna memutus rantai penularan penyakit covid-19.
\end{abstract}

Kata Kunci: Covid-29, Media Informasi, Motion Graphic

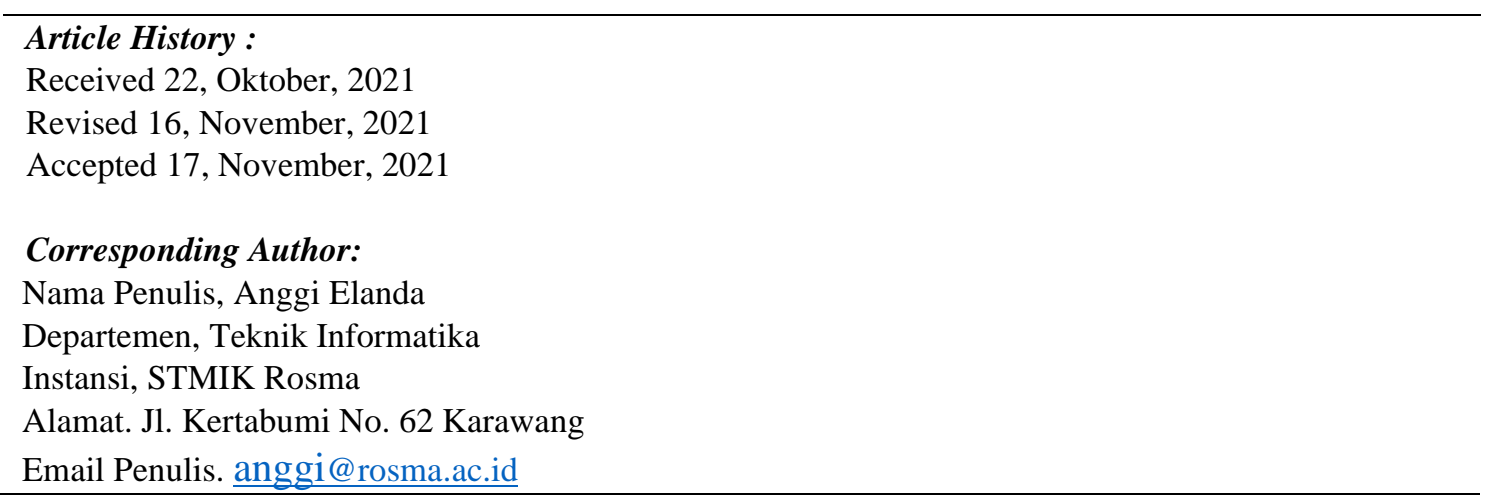

Jurnal Interkom: Jurnal Publikasi Ilmiah Bidang Teknologi Informasi dan Komunikasi

Volume 16 Nomor 03 Bulan Oktober - Tahun 2021 


\section{Pendahuluan}

Virus Corona atau severe acute respiratory syndrome coronavirus 2 (SARSCov-2) adalah virus yang menyerang sistem pernapasan. Penyakit karena infeksi virus ini disebut COVID-19. Virus Corona bisa menyebabkan gangguan ringan pada sistem pernapasan, infeksi paru-paru yang berat dan hingga dapat menyebabkan kematian. Virus Corona adalah jenis penyakit yang dapat menular pada manusia. Virus ini bisa menyerang siapa saja, seperti lansia (golongan usia lanjut), orang dewasa, anakanak, dan bayi, termasuk ibu hamil dan ibu menyusui [1]. Beberapa cara yang bisa dilakukan untuk mencegah tertularnya virus ini adalah :

a. Mencuci tangan dengan benar.

b. Menggunakan masker.

c. Menjaga daya tahan tubuh.

d. Menerapkan physical distancing dan isolasi mandiri.

e. Membersihkan rumah dan melakukan disinfeksi secara rutin.

Pada Data Pantauan Covid-19 Kabupaten Karawang update pada 30 April 2021 yang diumumkan oleh Satgas Covid19 pada website covid19.karawang.go.id adalah :

a. Total Konfirmasi sebanyak 18.686 orang.

b. Total Suspek sebanyak 8.081 orang.

c. Total Probabel sebanyak 87 orang.

d. Total Kontak Berat sebanyak 23.444 orang.

Jumlah tersebut terus mengalami pengurangan maupun penambahan di setiap harinya, yang dimana jumlah tersebut tidak dapat berkurang jika para masyarakat tidak dapat menjaga kesehatan serta tidak mematuhi protokol kesehatan.

Dari permasalahan yang ada saat ini mengenai penularan virus Covid-19 yang sangat cepat ini, penulis ingin membuat suatu media informasi yang dapat mengedukasi masyarakat agar patuh dalam mentaati protokol pencegahan dan penularan virus Covid-19. Meskipun sudah banyak video ataupun poster tentang himbauan atau informasi tentang virus ini, penulis yakin bila dengan membuat media informasi berupa video berbasis motion graphic masyarakat dapat lebih tertarik dalam melihatnya dan dapat dengan mudah menerapkan protokol kesehatan guna terhindar dari virus Covid-19 dalam kehidupan sehari - hari.

\section{Tinjauan Pustaka}

\subsection{Animasi}

Menurut Munir (2013:340) “animasi berasal dari bahasa inggris, animation dari kata to anime yang berarti "menghidupkan". Animasi merupakan gambar tetap (still image) yang disusun secara berurutan dan direkam dengan menggunakan kamera" [2]. Sedangkan menurut Vaughan dalam Binanto (2010:219) menyatahan bahwa "animasi adalah usaha untuk membuat presentasi statis menjadi hidup" [3]. Menurut pendapat beberapa ahli di atas maka dapat disimpulkan bahwa animasi merupakan sekumpulan gambar yang disusun secara berurutan dan direkam menggunakan kamera untuk membuat presentasi statis menjadi hidup.

\subsection{Multimedia}

Istilah multimedia berarti berbagai jenis sarana, usaha pembangunan untuk dunia komunikasi pendidikan atau penyedian informasi pada komputer yang menggunakan suara, grafika, animasi dan teks [4]. Multimedia adalah kombinasi dari komputer dan video atau Multimedia secara umum merupakan kombinasi tiga elemen, yaitu suara, gambar, teks atau Multimedia adalah kombinasi dari paling sedikit dua media input atau output dari data, media ini dapat audio (suara, musik), animasi, video, teks, grafik dan gambar atau Multimedia merupakan alat yang dapat menciptakan presentasi yang dinamis dan interaktif yang 
mengkombinasikan teks, grafik, animasi, audio dan gambar video [5].

\subsection{Storyboard}

Story Board adalah sejumlah sketsa yang menggambarkan aksi di dalam film, atau bagian khusus yang disusun teratur pada papan bulletin dan dilengkapi dengan dialog yang sesuai waktunya atau deskripsi adegan. Story board digunakan untuk mempermudah dan mempermurah pengambilan gambar [6].

\subsection{Motion Graphics}

Motion graphics bisa dikatakan sejenis dengan infographic, tetapi menggunakan cuplikan video atau animasi untuk membuat rangkaian gerak ilusi. Motion graphics pada umunnya merupakan gabungan dari potongan-potongan desain yang berbasis media visual yang menggabungkan bahasa film dengan desain grafis, seperti memasukan elemen-elemen yang berbeda seperti desain 2D atau 3D, animasi, video, ilustrasi, fotografi, dan musik. Termasuk di dalamnya yaitu, tipografi dan grafis yang dapat terlihat sebagai judul untuk film, pembuka program televisi, bumper, dan elemen \pm elemen grafis yang muncul di televisi. Namun, video atau film dari objek yang bergerak belum dikategorikan sebagai bagian dari motion graphics, kecuali jika video atau film tersebut dikombinasikan dengan beberapa elemen desain, seperti bentuk, jenis, atau baris [3].

\section{Metode Penelitian}

Metode pengembangan sistem yang digunakan dalam penelitian ini adalah Metode Pengembangan Multimedia LutherSutopo. Metode pengembangan multimedia terdiri dari enam tahap yaitu : concept (konsep), design (pendesainan), material collecting (pengumpulan materi), assembly (pembuatan), testing (pengujian), dan distribution (pendistribusian). Keenam tahap ini tidak harus berurutan dalam praktiknya, tahap-tahap tersebut dapat saling bertukar posisi [7].

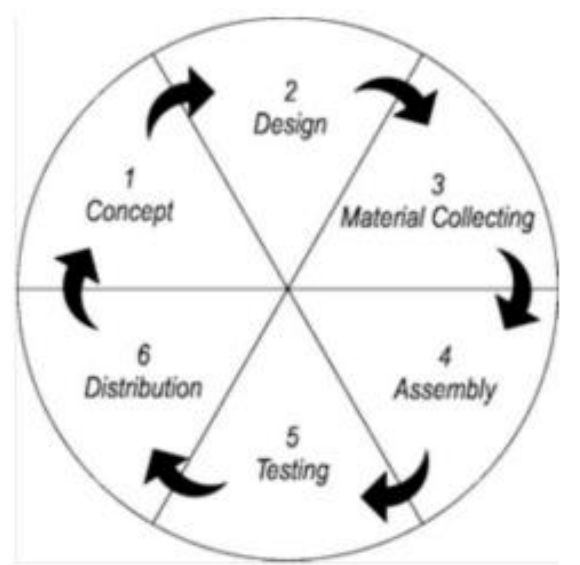

Gambar 2. Diagram Alir Luther Sutopo Sumber: [8]

\section{a. Concept}

Tahap konsep adalah tahap untuk menentukan tujuan dan siapa pengguna program. Selain itu menentukan macam aplikasi (presentasi, interaktif, dan lain lain) dan tujuan aplikasi (hiburan, pelatihan, pembelaran, dan sebagainya) harus berpengaruh pada nuansa multimedia sebagai pencerminan dari identitas organisasi yang mengingikan informasi sampai pada pengguna akhir. Dasar aturan untuk perancangan juga ditentukan pada tahap ini, misalnya ukuran aplikasi, target, dan lain-lain, output dari tahap ini biasanya berupa dokumen yang bersifat naratif untuk mengungkapkan tujuan projek yang ingin dicapai. Berdasarkan konsep multimedia yang akan dikembangkan, maka harus membuat deskripsi dari konsep yang akan dibuat.

b. Design

Design (perancangan) adalah tahap membuat spesifikasi mengenai arsitektur program, gaya, tampilan dan kebutuhan material/bahan untuk 
program. Spesifikasi dibuat serinci mungkin sehingga pada tahap berikutnya, yaitu material collecting dan assembly pengambilan keputusan tidak perlu , pada tahap ini harus menggunakan storyboard untuk menggambarkan deskripsi tiap scene, dengan mencantumkan semua objek multimedia dan tautan scene yang lain dengan bagan alir untuk menggambarkan aliran dari satu scene ke scene yang lain.

c. Material Collecting

Material Collecting adalah tahap dimana mengumpulkan bahan semua objek atau bahan multimedia dibuat berdasarkan sesuai dengan kebutuhan. Bahan-bahan tersebut bisa gambar, foto, animasi, video, audio dan lain-lain yang diperoleh secara gratis bisa melalui internet, Tahap ini dapat dikerjakan paralel dengan tahap assembly. Pada beberapa kasus, tahap material collecting dan tahap assembly akan dikerjakan secara linear tidak paralel Assembly Tahap Assembly (pembuatan) adalah tahap pembuatan semua objek atau bahan multimedia. Pembuatan aplikasi didasarkan pada tahap desain, tahap ini menggunakan berbagai aplikasi pendukung dalam pembuatan visualisasi, objek gambar, dan lainnya seperti aplikasi blender 3d, eclipseTesting Tahap Testing Dilakukan setelah selesai tahap pembuatan (assembly) yaitu dengan menjalankan aplikasi/program. Tahap pertama dalam pengujian ini menggunakan alpha test yang mengujiannya dilakukan oleh pembuat atau lingkungan pembuatnya sendiri,

d. Distribution

Tahapan dimana aplikasi disimpan dalam suatu media penyimpanan, kemudian didistribusikan kepada pihak pengguna. Pada tahap ini jika media penyimpanan tidak cukup menampung aplikasinya, maka dilakukan kompresi terhadap aplikasi tersebut, tahap ini juga disebut tahap evaluasi untuk pengembangan produk yang sudah jadi agar menjadi lebih baik, hasil evaluasi dapat digunakan sebagai masukan untuk tahap concept pada produk selanjutnya.

\section{Hasil dan Pembahasan}

\subsection{Konsep}

Pada tahap pengonsepan dibuat storyline. Storyline merupakan rancangan kasar sedangkan storyboard merupakan rancangan yang lebih terpadu. Storyline produk ini adalah sebagai berikut :

a. Intro video

b. Menampilkan logo STMIK Rosma

c. Menampilkan Isi video yang terdiri dari: 3M, Memakai masker, Mencuci Tangan, dan Menjaga Jarak

d. Menampilkan pesan mematuhi protokol Kesehatan

\subsection{Desain}

Pada tahap desain dibuat storyboard. Storyboad adalah sketsa gambar yang disusun berurutan sesuai dengan naskah. Storyboard yang digunakan dapat dilihat dalam tabel sebagai berikut :

Tabel 1. Storyboard

\begin{tabular}{|c|c|c|}
\hline Scene & Board & Deskripsi \\
\hline 1. & $\begin{array}{c}\text { MENERAPKAN PROTOKOL } \\
\text { KESEHATAN }\end{array}$ & Intro, menampilkan judul video \\
& META & \\
\hline
\end{tabular}




\begin{tabular}{|c|c|c|}
\hline Scene & Board & Deskripsi \\
\hline 2. & 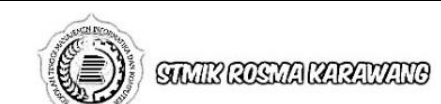 & $\begin{array}{l}\text { Menampilkan tulisan "STMIK ROSMA } \\
\text { Karawang" sebagai penyambung intro }\end{array}$ \\
\hline 3. & $\begin{array}{l}\text { Ayokite Ceegeh } \\
\text { Penuflaran Vitus Gorrna }\end{array}$ & $\begin{array}{l}\text { Menampilkan tulisan "Ayo Kita Cegah } \\
\text { Penularan Virus Corona" sebagai isi video }\end{array}$ \\
\hline 4. & DENGAN CARA & Menampilkan tulisan "Dengan Cara :" \\
\hline 5. & TERAPKAN & Menampilkan tulisan "Terapkan 3M" \\
\hline 6. & memarat mastre & Menampilkan tulisan "Memakai Masker" \\
\hline 7. & 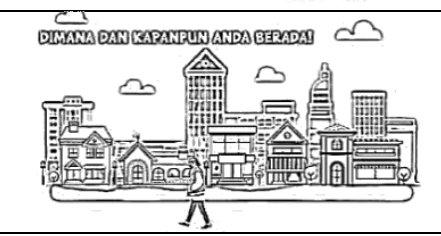 & $\begin{array}{l}\text { Menampilkan tulisan "Dimana pun dan } \\
\text { Kapanpun Anda Berada" }\end{array}$ \\
\hline 8. & CIENGUUM TANGAN & Menampilkan tulisan "Mencuci Tangan" \\
\hline 9. & 酶) & $\begin{array}{l}\text { Menampilkan tulisan "Dengan Sabun atau Hand } \\
\text { Sanitizer" }\end{array}$ \\
\hline 10. & 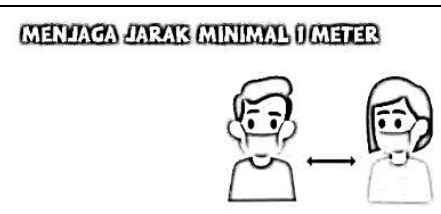 & Menampilkan tulisan "Menjaga Jarak" \\
\hline 11. & 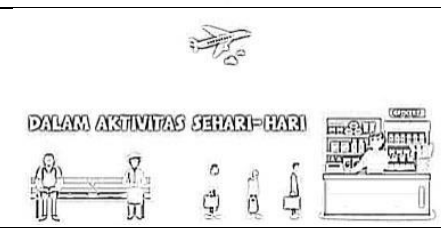 & $\begin{array}{l}\text { Menampilkan tulisan "Dalam Aktivitas Sehari- } \\
\text { hari" }\end{array}$ \\
\hline 12. & $\begin{array}{l}\text { LINDUNGI DIRI ANDA } \\
\text { DAN ORANG DI SEKITAR ANDA }\end{array}$ & $\begin{array}{l}\text { Menampilkan tulisan "Lindungi Diri Anda dan } \\
\text { Orang disekitar Anda" sebagai Scene Akhir } \\
\text { Video }\end{array}$ \\
\hline 13. & DENGAN PATUHI PROTOKOL KESEHATAN & $\begin{array}{l}\text { Menampilkan tulisan "Dengan Patuhi Protokol } \\
\text { Kesehatan" sebagai lanjutan dari Scene Akhir } \\
\text { Video }\end{array}$ \\
\hline
\end{tabular}

\subsection{Material Collecting}

Penulis mendapat gambar stock yang bersifat free license dari situs freepik.com dan mengambil audio yang bersifat free license dari situs soundcloud.com untuk membuat keseluruhan bahan yang 
dibutuhkan dalam pembuatan video motion graphic yang dibuat oleh penulis. Berikut adalah gambar stock yang dipakai dalam pembuatan video edukasi:
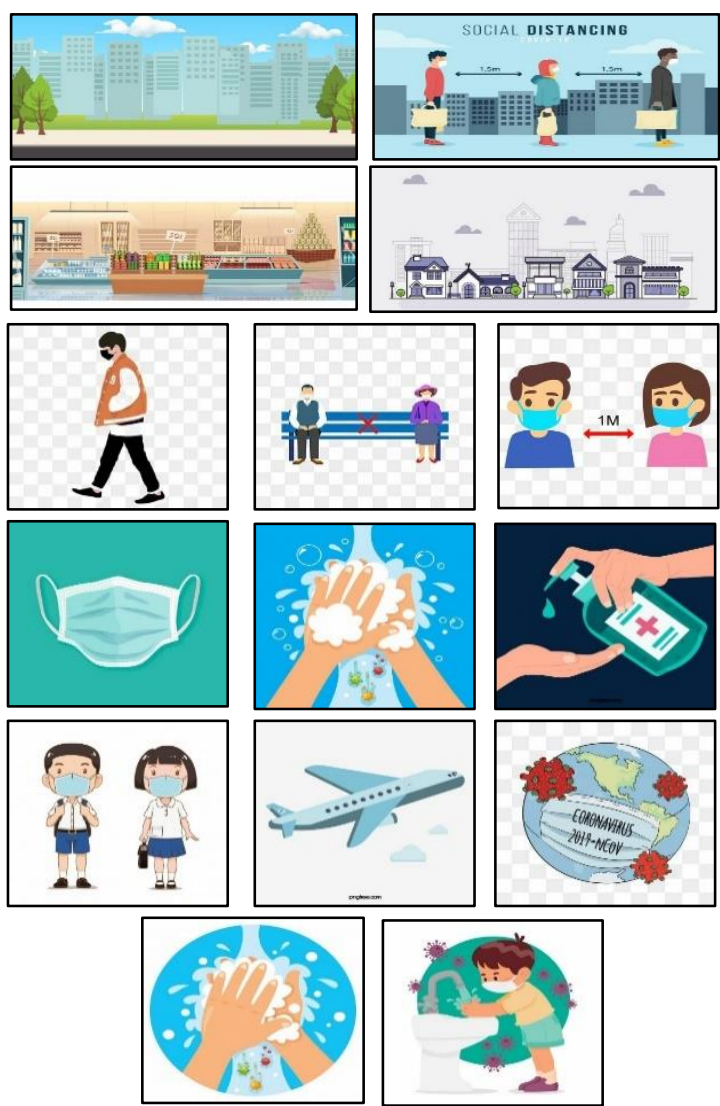

Gambar 3. Stock dalam Pembuatan Video

\subsection{Assembly}

Tahap ini merupakan tahap penyusunan dan pengkomposisian bahan-bahan, pada tahap ini animasi dibuat dengan menggunakan aplikasi edit video kinemaster versi android. Bahan-bahan yang dikomposisikan adalah gambar, efek visual, efek transisi serta musik latar. Berikut adalah tahapan-tahapan dalam mengedit video:

Tabel 2. Tahapan dalam Pembuatan Video

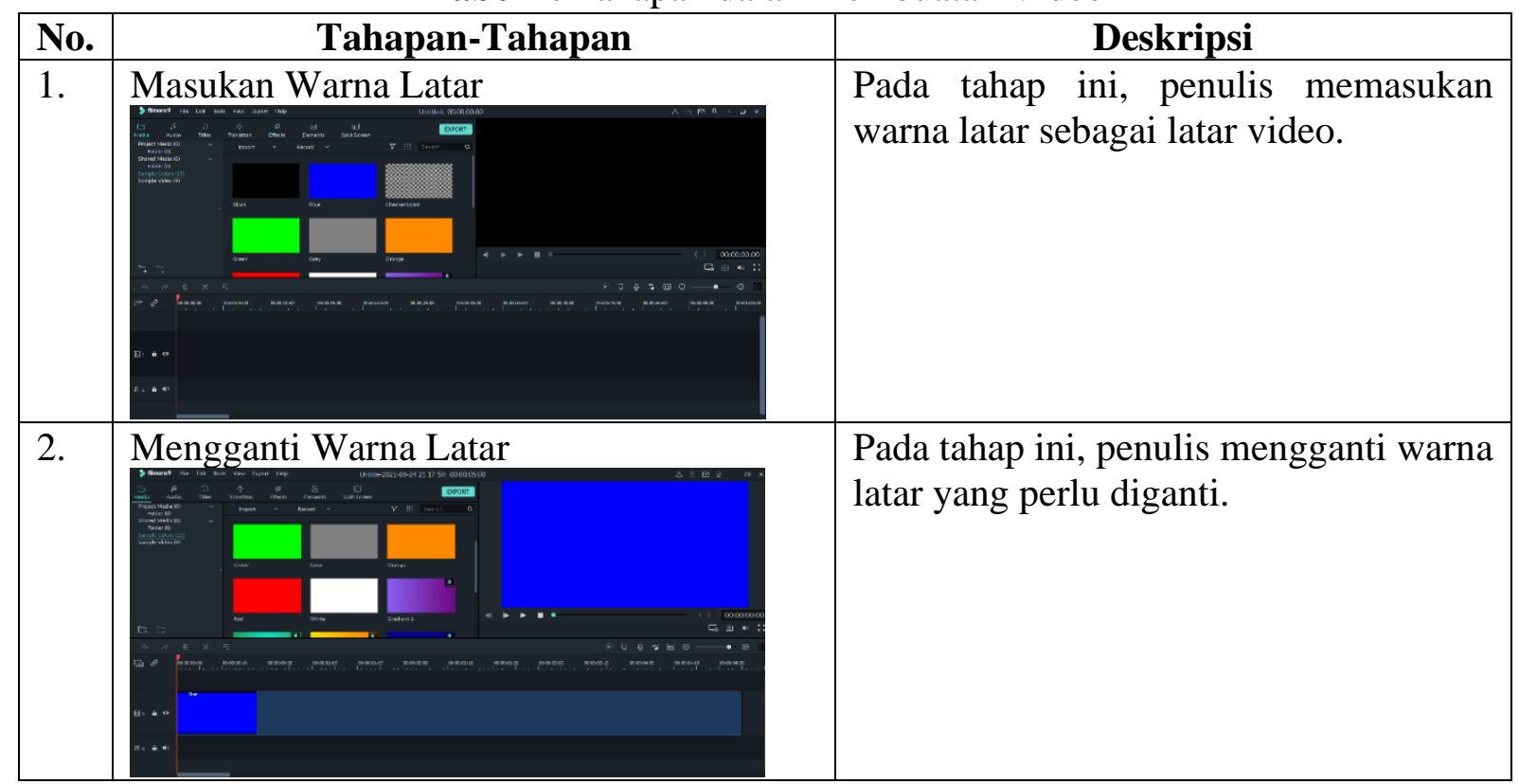




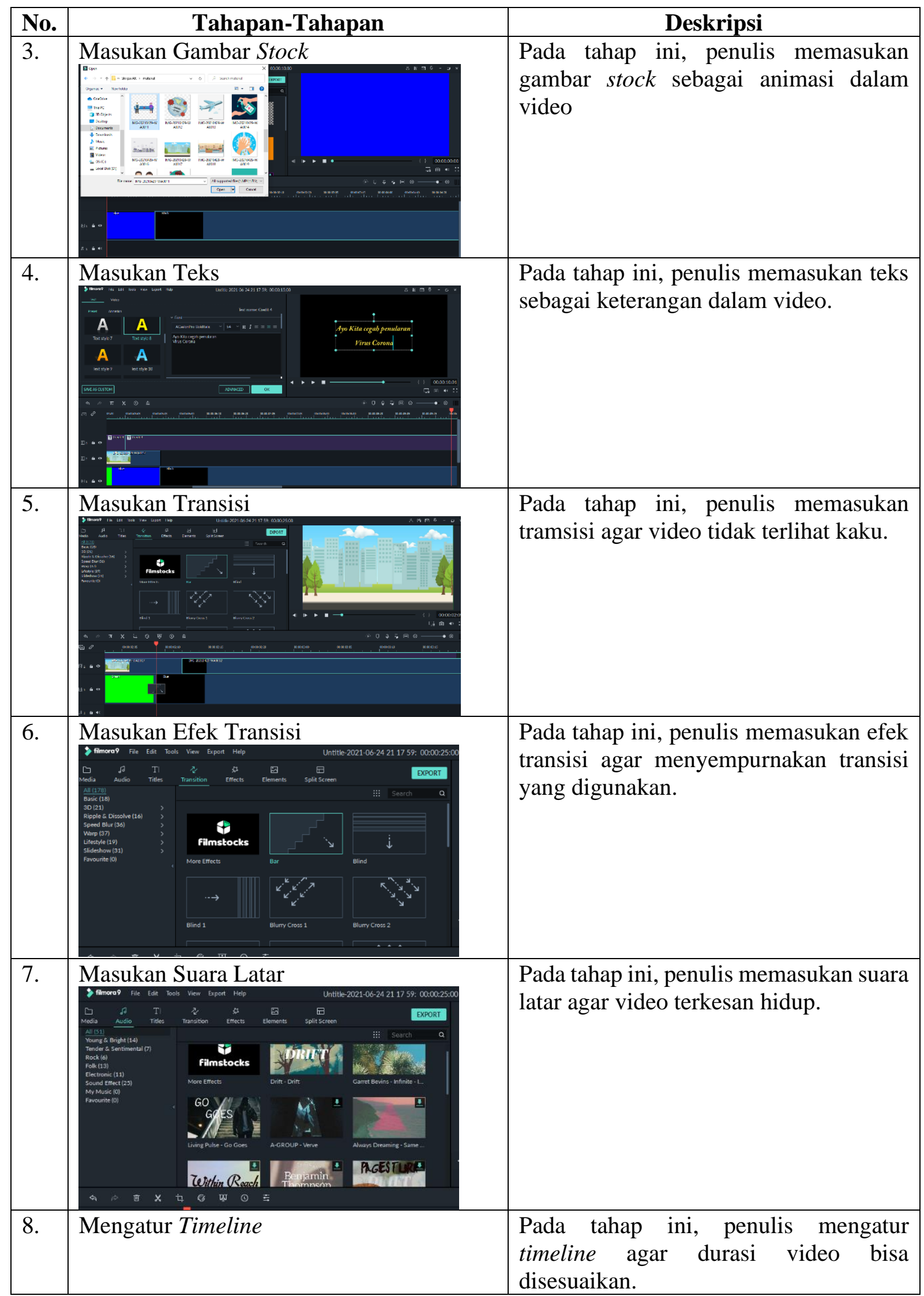

Jurnal Interkom: Jurnal Publikasi Ilmiah Bidang Teknologi Informasi dan Komunikasi

Volume 16 Nomor 03 Bulan Oktober - Tahun 2021 


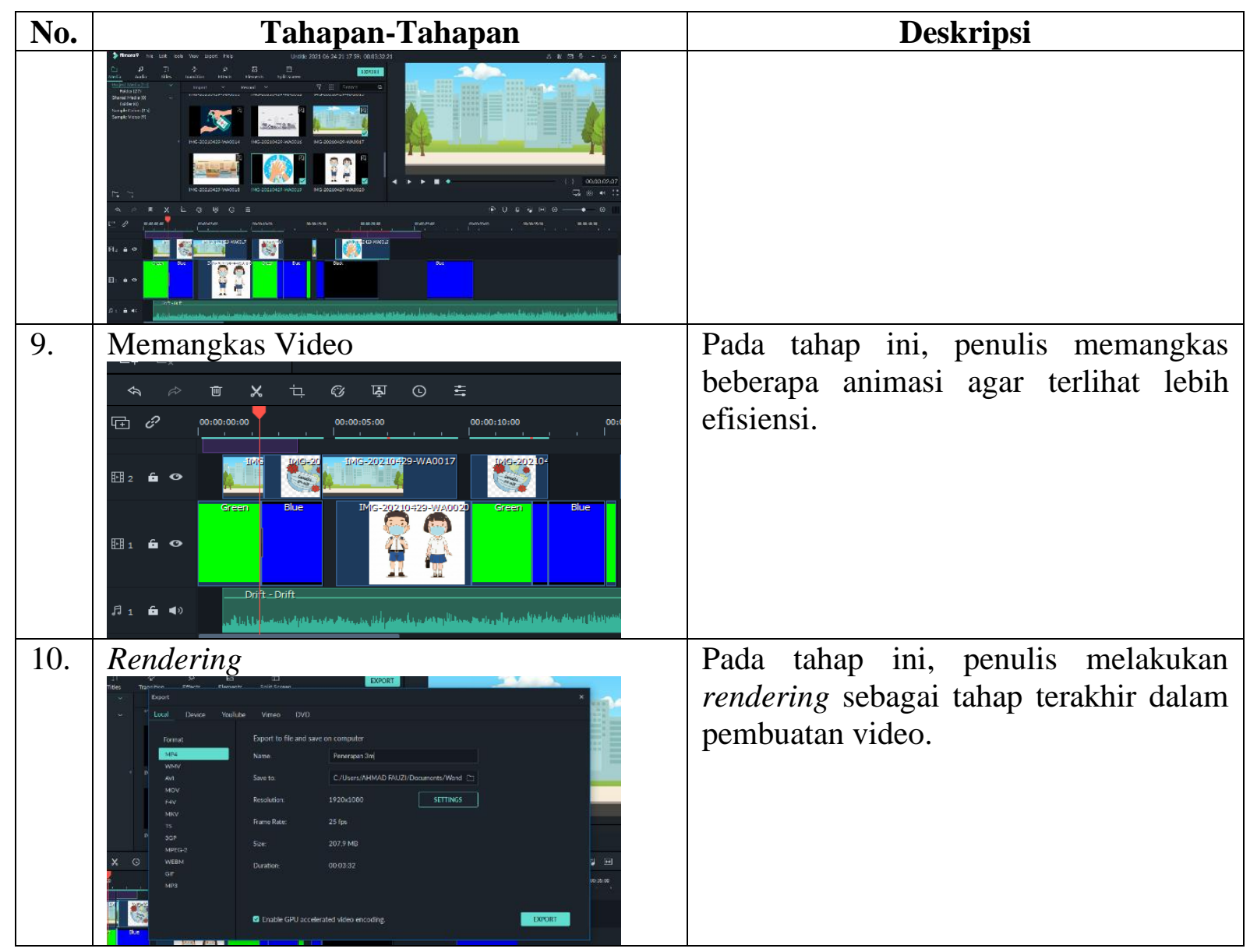

\subsection{Testing}

Uji kelayakan produk diuji melalui kuesioner yang via google form, hasil yang didapatkan yaitu sekitar 54 responden dari berbagai kalangan yang disebarkan secara acak dan didapat berdasarkan jangka waktu yang telah ditentukan yaitu dari tanggal 29 Maret 2021 sampai dengan 19 April 2021. Berikut adalah hasil uji kelayakan produk melalui kuesioner :

Tabel 4.1 Hasil Uji Kelayakan Produk melalui Kuesioner

\begin{tabular}{|c|l|c|c|c|}
\hline No. & \multicolumn{1}{|c|}{ Pertanyaan } & $\begin{array}{c}\text { Skor yang di } \\
\text { dapat }\end{array}$ & $\begin{array}{c}\text { Skor } \\
\text { maksimum }\end{array}$ & Kelayakan \\
\hline 1. & Penilaian video yang ditampilkan & 50 & 54 & $92,5 \%$ \\
\hline 2. & Kualitas video yang ditampilkan & 48 & 54 & $88,8 \%$ \\
\hline 3. & $\begin{array}{l}\text { Musik latar video yang } \\
\text { ditampilkan }\end{array}$ & 52 & 54 & $96,2 \%$ \\
\hline 4. & Penyampaian pesan dalam video & 47 & 54 & $87 \%$ \\
\hline 5. & $\begin{array}{l}\text { Respon dari setiap responden } \\
\text { mengenai video yang ditampilkan }\end{array}$ & 45 & 54 & $83,3 \%$ \\
\hline \multicolumn{2}{|}{ Total Rata - Rata } & $\mathbf{2 4 2}$ & $\mathbf{2 7 0}$ & $\mathbf{8 9 , 6 \%}$ \\
\hline
\end{tabular}




\subsection{Distribution}

Hasil dari perancangan video Motion Graphic yang berisikan tentang Video Edukasi Penerapan Protokol Kesehatan disajikan dalam sebuah video yang berdurasi 48 detik. Video dibuat sedemikian rupa dengan desain yang mudah pahami oleh masyarakat luas. Selain itu juga video di upload ke YouTube dan media social lainya. Hal ini agar siapapun dapat dengan mengakses dan menonton video tersebut dengan mudah. Berikut adalah screenshoot dari isi video :
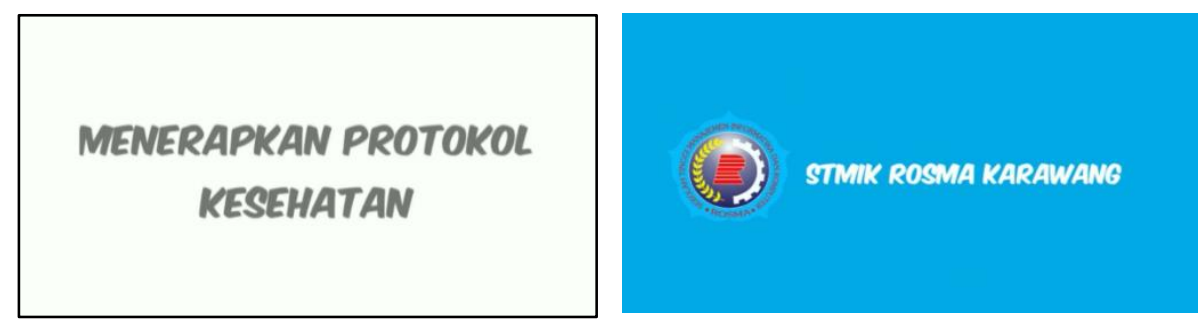

Gambar 4. Intro Video
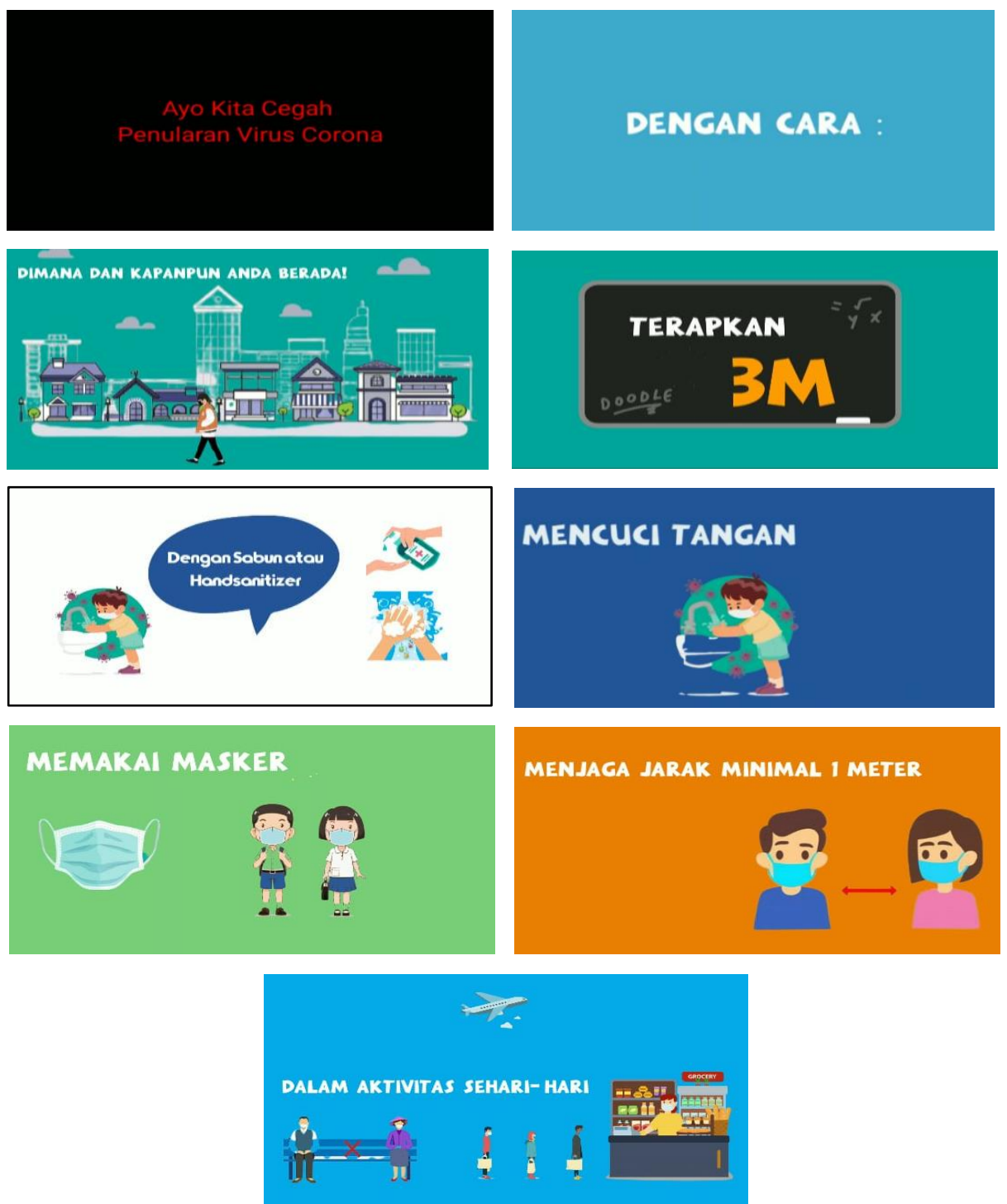

Gambar 5. Isi Video

Jurnal Interkom: Jurnal Publikasi Ilmiah Bidang Teknologi Informasi dan Komunikasi

Volume 16 Nomor 03 Bulan Oktober - Tahun 2021 

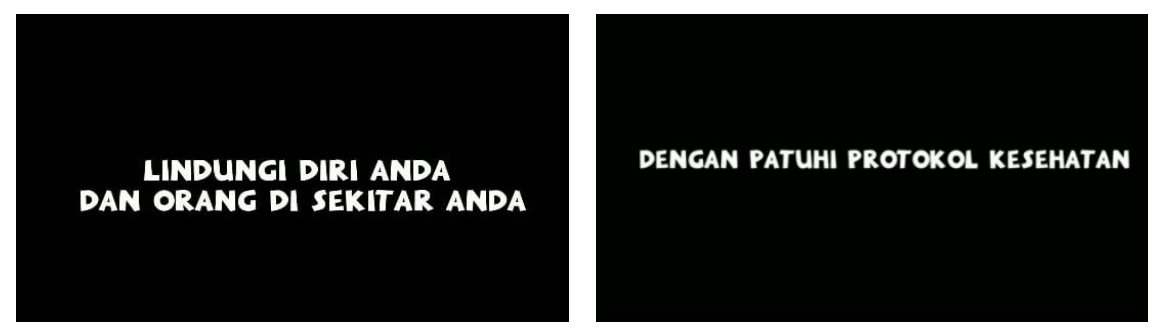

Gambar 6. Penutup Video

\section{Kesimpulan}

Berdasarkan hasil penelitian dalam laporan ini maka dapat disimpulkan bahwa:

a. Materi disusun berdasarkan dari data yang didapat dan memungkinkan untuk diolah untuk kemudian bisa ditampilkan.

b. Produk video edukasi penerapan protokol kesehatan pencegahan covid19 berbasis motion graphic diproduksi dengan menggunakan software Kinemaster versi Android untuk video editing.

c. Sebanyak $89,6 \%$ dari responden sudah memberikan nilai untuk uji kelayakan setelah menonton video edukasi berbasis motion graphic tersebut hingga termasuk dalam kategori "Sangat Baik."

\section{Daftar Pustaka}

[1] https://dinkes.bulelengkab.go.id/, "Penyebab, Gejala dan Pencegahan Virus Corona," Dinas Kesehatan, 2021. [Online]. Available: https://dinkes.bulelengkab.go.id/infor masi/detail/artikel/84-penyebabgejala-dan-pencegahan-virus-corona.

[2] M. Santoso, S. A., \& Chotibuddin, PEMBELAJARAN BLENDED LEARNING MASA PANDEMI . Penerbit Qiara Media., 1st ed. Pasuruan, Jawa Timur: CV. Penerbit Qiara Media, 2020.

[3] R. Risandhy and M. F. Baihaqi, "PERANCANGAN FILM ANIMASI 2D \& 3D KEANEKARAGAMAN
BATIK INDONESIA," Warn. (Journal Vis. Commun. Des., vol. 1, no. 1, pp. 11-30, 2020.

[4] M. N. T. Rifai and T. I. TJ, "Pembuatan Bilingual Video Profil Pada Sekolah Menengah Kejuruan Negeri 9 Surakarta," in Seminar Riset Unggulan Nasional Informatika dan Komputer FTI UNSA 2013, 2013, pp. 35-40.

[5] H. Syafwan, P. Putri, and M. Mariana, "Perancangan Media Pembelajaran Kimia Tentang Struktur Atom Berbasis Multimedia," in Prosiding Seminar Nasional Riset Information Science (SENARIS), 2019, pp. 10021009, doi: 10.30645/senaris.v1i0.110.

[6] S. D. Saftanto, "Pembuatan Video Company Profile Berbasis Multimedia Pada Sekolah Menengah Pertama Negeri 4 Karanganyar," Seruni-Seminar Ris. Unggulan Nas. Inform., vol. 1, no. 1, pp. 238-241, 2013.

[7] P. A. Nanda, "Simulasi Visualisasi Teknik Gerakan Yoga Dengan Metode Pengembangan Multimedia Luther-Sutopo Berbasis Mobile," JURIKOM (Jurnal Ris. Komputer), vol. 7, no. 2, p. 207, 2020, doi: 10.30865/jurikom.v7i2.1944.

[8] B. Wulandari, F. Ardiansyah, P. Eosina, and H. Fajri, "Media Pembelajaran Interaktif Ipa Untuk Sekolah Dasar Berbasis Multimedia," Krea-Tif, vol. 7, no. 1, p. 11, 2019, doi: 10.32832/kreatif.v7i1.2028. 